\title{
Boxing Competitors Being the Exception; Judo, 1500 m Running, and Marathon Running Competitors at the 2012 London Olympic Games Held Inadequate Ages, Heights and/or Weights That Contributed to the Humiliating Defeats of Democratic Republic of the Congo
}

\author{
André Mukala Nsengu Tshibangu \\ Department of Basic Sciences, Faculty of Pharmaceutical Sciences, University of Kinshasa, Kinshasa, Democratic \\ Republic of the Congo \\ Email: andre28080@lycos.com
}

Received 24 August 2015; accepted 27 November 2015; published 30 November 2015

Copyright @ 2015 by author and Scientific Research Publishing Inc.

This work is licensed under the Creative Commons Attribution International License (CC BY).

http://creativecommons.org/licenses/by/4.0/

(c) (i) Open Access

\section{Abstract}

There exist many factors that may have influenced the performance of the only four Democratic Republic of the Congo (DRC) competitors at the 2012 London Olympic Games. However, in the present article, the attention is focused only on available anthropometric factors. Computer carried out the analysis of the ages, heights and/or weights of all the competitors of some divisions at the 2012 London Olympic Games [super heavyweight male boxers (more than $91 \mathrm{~kg}$ ); male judokas weighing $100 \mathrm{~kg}$ and over; women who ran the $1500 \mathrm{~m}$ race; and men who ran the marathon]. An examined clip showed the contribution of factors others than anthropometric to the early defeat of the Congolese boxer Mwamba Meji at the 2012 London Olympic Games (inadequate wearing of boxing helmet, wearing of boots inappropriate to boxing practice, the imperfection of boxing guard, errors of tactics, face showing fear of the opponent's attacks). None of the three aforesaid anthropometric factors contributed to the boxer's defeat. Inadequate anthropometric factors that caused early defeats of the three other Congolese competitors at the 2012 London Olympic Games were: 1) the relative age of the male judoka Mandembo Cedric when compared with that of his opponent, and his too short absolute height; 2 ) the too young age, the too short height and the too light weight of the $1500 \mathrm{~m}$ female runner Ilunga Sankuru Chancel; as well as 3) the too young age and the too short height of the marathon male runner Ilunga Zatara Mande.

How to cite this paper: Tshibangu, A. M. N. (2015). Boxing Competitors Being the Exception; Judo, $1500 \mathrm{~m}$ Running, and Marathon Running Competitors at the 2012 London Olympic Games Held Inadequate Ages, Heights and/or Weights That Contributed to the Humiliating Defeats of Democratic Republic of the Congo. Advances in Physical Education, 5, 286-298. 


\section{Keywords}

\section{2, 1500 m, Age, Anthropometry, Boxing, Distance, Games, Height, Judo, London, Marathon, Middle, Muhammad Ali, Olympic, Running, Tactics, Weight}

\section{Introduction}

\subsection{Anthropometric Factors May Be Taken into Account during Identification of Competitors More Advantaged than Others, and during Selection of Candidates for Competition}

If sport talent is to be fully developed, coaching based on sound sport science principles is an essential ingredient while "raw athletic talent" is the most important factor in the attainment of high levels of sporting performance (Ackland, Bloomfield, \& Elliot, 2009).

Olds \& Tomkinson (2009) point out, on one hand, that success in a given sport depends on a mixture of physiologic, psychological and anthropometric characters which vary from one sport to another and, on the other hand, that general tendency is towards heterogeneity of physical characters between sports but towards homogeneity of those characters in each sport.

Inasmuch as given anthropometric factors influence performances of competitors, it may thus be expected the more advantaged competitors to close together in the values of the anthropometric factors, ideal values from which are more and more distant values held by the less advantaged competitors, as the advantage decrease. In the case that ideal values underlie success in given sports, they may then be taken into account when recruiting sportsmen and sportswomen or when selecting them for competition.

\subsection{Objective of the Present Article}

Writing the present article has been motivated by the desire to share with the readers the possible contribution of anthropometric factors to the humiliating defeats of the only four Democratic Republic of Congo (DRC) competitors at the 2012 London Olympic Games: 1) DRC male super heavyweight boxer Mwamba Meji (more than $91 \mathrm{~kg}$ ) was defeated in their battle with Azerbaijan boxer Medzhidov Magomedrasul, Mwamba's only battle in the Games; 2) DRC male judoka Mandembo Cedric (100 kg and over) was also defeated in their battle with Russia judoka Mikhaylin Alexander, Mandembo's only battle in the Games; 3) among the 22 women who have been eliminated in the first round of the $1500 \mathrm{~m}$ running in the Games, DRC runner Ilunga Sankuru Chancel came last; and 4) among the 105 men who ran the marathon in the Games, DRC runner Ilunga Zatara Mande was one of the 20 who did not finish the race.

In the case that the suspected contribution of anthropometric factors was real, taking it into account in the future 1) could help correct possible selection mistakes that could have contributed to the defeat as well as it 2) could help either modulate anthropometric factors unfavorable to success, or optimize other factors that possibly influence the performances of male boxers (more than $91 \mathrm{~kg}$ ), male judokas (100 kg and over), female $1500 \mathrm{~m}$ runners, and male marathon runners.

\section{Material and Methods}

\subsection{Anthropometric Factors of DRC Competitors That Have Been Mentioned by the Official Website of the London 2012 Olympic Games and Paralympic Games}

The subjects enrolled in the present study are the DRC four competitors who participated to the London 2012 Olympic Games and Paralympic Games in male boxing (more than $91 \mathrm{~kg}$ ), male Olympic judo (100 kg and over), women $1500 \mathrm{~m}$ running, and male marathon running, respectively.

Insofar as the concerned anthropometric values have reached the webmaster, the Official website of the London 2012 Olympic Games and Paralympic Games mentions with precision the age and height of each male boxer, each male judoka, each woman running $1500 \mathrm{~m}$ and each male running the marathon (The London Organising Committee of the Olympic Games and Paralympic Games Limited, 2012a, b, c, d).

Furthermore, the website mentions the weight of each male judoka, each woman running the $1500 \mathrm{~m}$ and each 
male running the marathon.

Possibly because boxers are split up into weight categories in each of which weight differences between boxers are assumed to have no influence on the battle result, the website has not mentioned with precision the weights of the boxers but has mentioned instead the name of the weight division to which belongs each boxer.

\subsection{Analysis of Anthropometric Data Concerned in the Present Study}

Microsoft Office Excel 2007 program has been used in the analysis of anthropometric data gathered in the Official website of the London 2012 Olympic Games and Paralympic Games about the DRC competitors who participated in the Games: ages and heights of super heavyweight boxers (more than $91 \mathrm{~kg}$ ); ages, heights and weights of judokas weighing $100 \mathrm{~kg}$ and over; ages, heights and weights of women who ran the $1500 \mathrm{~m}$ race; and ages, heights and weights of men who ran the marathon.

There was a need to conclude in the existence or the non existence of relationships (either positive or negative) between sets of data pairs: each available anthropometric variable value (age, height and/or weight) on one hand, and on the other hand the relative merits of the competitors. To meet the purpose, scatter diagrams have been plotted to represent each pair of variables (Parker, 1979).

A clip on the boxing battle that opposed Mwamba Meji to Medzhidov Magomedrasul has been viewed (Chaîne de Congomikilinews, 2012), while neither film nor clip has been viewed 1) on the judo battle that opposed Mandembo Cedric to Mikhaylin Alexander; 2) on the women who ran the $1500 \mathrm{~m}$, and 3) on the men who ran the marathon.

\subsection{Splitting up of Competitors According to Relative Merits Classes in Arbitrarily Chosen Units}

In the present article, boxers have been split up into five merits classes in arbitrarily chosen units: 1 (those who have been won in the round before the quarterfinals), 2 (those who have been won in the quarterfinals), 3 (those who have been won in the semifinals), 4 (the one who has been won in the final), and 5 (the one who won in the final).

Judokas have been split up into seven merits classes in arbitrarily chosen units: 1 (those who have been won in the elimination round of 32), 2 (those who have been won in the elimination round of 16), 3 (those who have been won in the quarterfinals), 4 (those who have been won in the contest for bronze medal), 5 (those who have been won in the semifinals), 6 (the one who has been won in the final), and 7 (the one who won in the final).

$1500 \mathrm{~m}$ runners have been split up into three merits classes in arbitrarily chosen units: 1 (those who have been eliminated in the first round), 2 (those who have been eliminated in the semifinal), and 3 (those who competed in the final).

Marathon runners have been split up into eight merits classes in arbitrarily chosen units: 1 (the 25 runners who did not finish the race), 2 (the 13 runners classed $73^{\text {rd }}$ to $85^{\text {th }}$ at the end of the race), 3 (the 12 runners classed $61^{\text {st }}$ to $72^{\text {nd }}$ at the end of the race), 4 (the 12 runners classed $49^{\text {th }}$ to $60^{\text {th }}$ at the end of the race), 5 (the 12 runners classed $37^{\text {th }}$ to $48^{\text {th }}$ at the end of the race), 6 (the 12 runners classed $25^{\text {th }}$ to $36^{\text {th }}$ at the end of the race), 7 (the 12 runners classed $13^{\text {th }}$ to $24^{\text {th }}$ at the end of the race) and 8 (the 12 runners classed $1^{\text {st }}$ to $12^{\text {th }}$ at the end of the race).

To split up into classes the 85 marathon runners who finished the race, Sturges' rule (Daniel, 1987) has been used: if " $n$ " is the number of values in the data set under consideration; if " $k$ " stands for the number of class intervals; if " $R$ ", the range, is the difference between the smallest and the largest observation in the data set; and if " $w$ " is the class interval width; the Sturges' rule is given by Equation (1); and the width of each class interval is given by Equation (2).

$$
\begin{gathered}
k=1+3.322(\log n) \\
w=R \cdot k^{-1}
\end{gathered}
$$

Thus, the 85 male marathon runners have been split up into seven classes (six classes of 12 runners and one class of 13 runners).

\section{Results}

\subsection{Influence of the Means of the Ages of the Boxers}

Regarding the influence of the means of the ages of the boxers (Table 1 and Figure 1), it appears that, with in- 


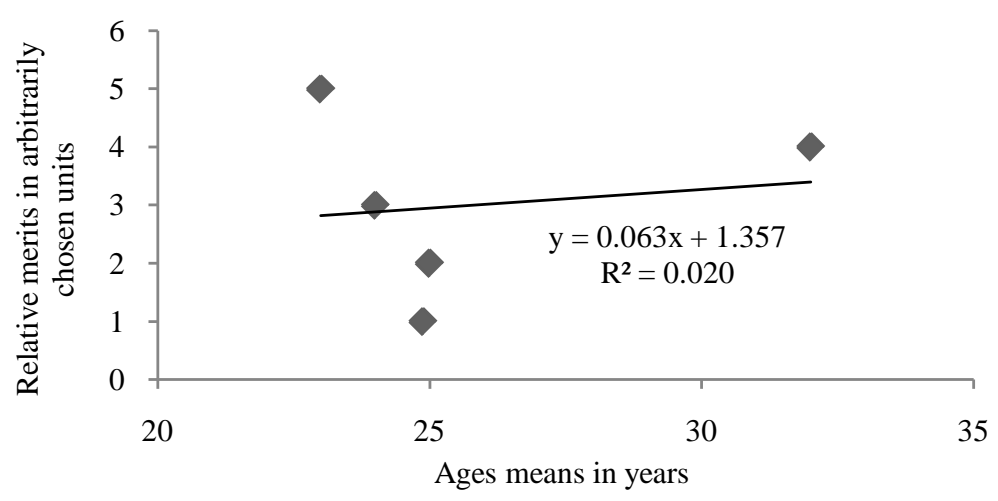

Figure 1. Relative merits at different ages means of the boxers. With increasing mean age, there is a trend towards an increase of relative merit.

Table 1. Rankings, ages means, heights means, and relative merits of male super heavyweight boxers (more than $91 \mathrm{~kg}$ ) who competed at the 2012 London Olympic Games.

\begin{tabular}{|c|c|c|c|}
\hline Rankings & Ages means (years) & Heights means $(\mathrm{cm})$ & $\begin{array}{c}\text { Relative merits } \\
\text { (arbitrarily chosen units) }\end{array}$ \\
\hline the boxer who won in the final & 23 & 198 & 5 \\
\hline the boxer who has been won in the final & 32 & 191 & 4 \\
\hline the boxers who have been won in the semifinals & 24 & 197.5 & 3 \\
\hline the boxers who have been won in the quarterfinals & 25 & 197 & 2 \\
\hline $\begin{array}{l}\text { the boxers who have been won } \\
\text { in the round before the quarterfinals }\end{array}$ & 24.9 & 192.9 & 1 \\
\hline
\end{tabular}

creasing mean age, there is a trend towards an increase of relative merit. The Congolese boxer Mwamba Meji was 30 years old when he was defeated as soon as the round before the quarterfinals by Medzhidov Magomedrasul who was then 26 years old but was himself defeated only during the semifinal. The age of each of both boxers was then greater than the mean of the ages of all the boxers of their boxing division pulled together (25.8 years).

\subsection{Influence of the Means of the Heights of the Boxers}

Regarding the influence of the heights of the means of the boxers (Table 1 and Figure 2), it appears that, with increasing mean height, there is a trend towards an increase of relative merit. The Congolese boxer Mwamba Meji was $195 \mathrm{~cm}$ tall when he was defeated as soon as the round before the quarterfinals by Medzhidov Magomedrasul who was then $190 \mathrm{~cm}$ tall but was himself defeated only during the semifinal. Of both boxers, it was the Congolese boxer who held then a height closer to the mean of the heights of all the boxers of their boxing division pulled together $(195.3 \mathrm{~cm})$.

\subsection{Influence of the Means of the Ages of the Judokas}

Regarding the influence of the means of the ages of the judokas (Table 2 and Figure 3), it appears that, with increasing mean age, there is a trend towards an increase of relative merit. The Congolese judoka Mandembo Cedric was 28 years old, an age as old as the mean of the ages of all the judokas of their judo division pulled together, when he was defeated as soon as the elimination round of 32 by Mikhaylin Alexander who was then 33 years old but who was himself defeated only during the final.

\subsection{Influence of the Means of the Heights of the Judokas}

Regarding the influence of the means of the heights of the judokas (Table 2 and Figure 4), it appears that, with increasing mean height, there is a trend towards an increase of relative merit. The Congolese judoka Mandembo 


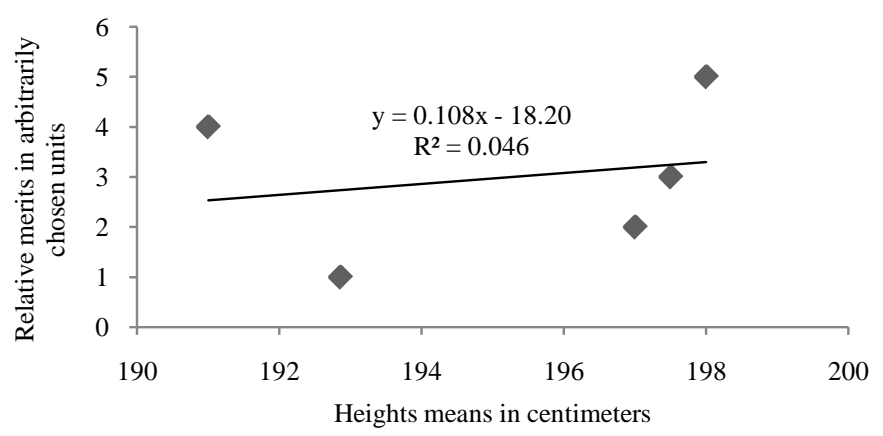

Figure 2. Relative merits at different heights means of the boxers. With increasing mean height, there is a trend towards an increase of relative merit.

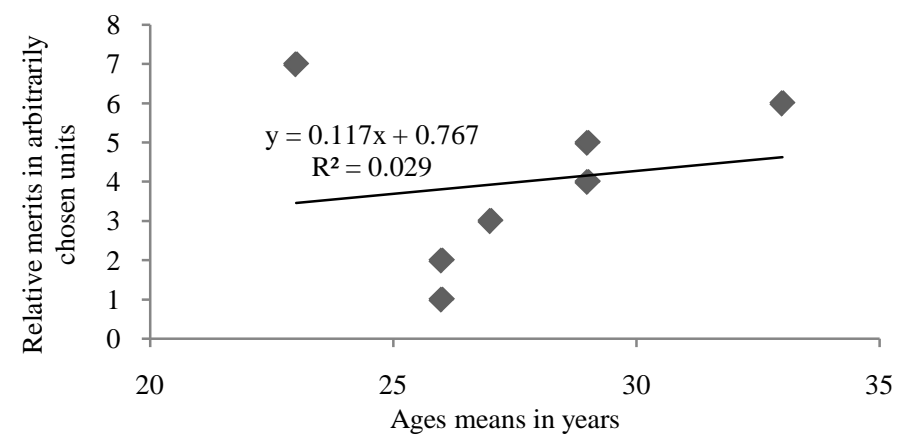

Figure 3. Relative merits at different ages means of the judokas. With increasing mean age, there is a trend towards an increase of relative merit.

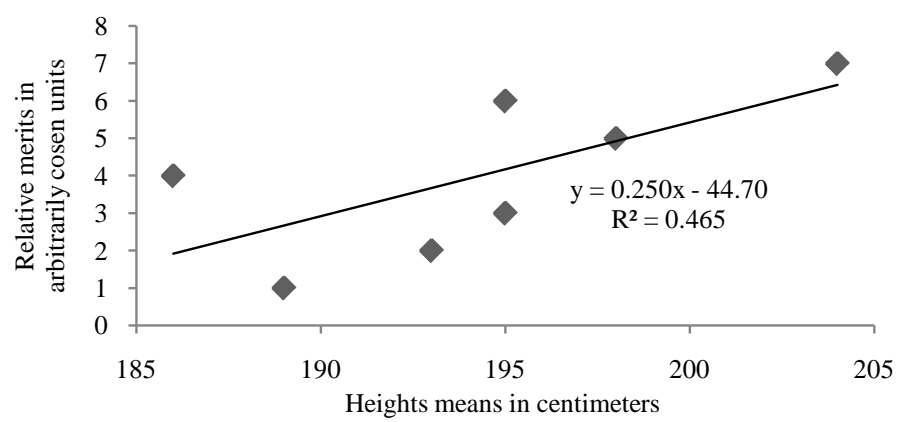

Figure 4. Relative merits at different heights means of the judokas. With increasing mean height, there is a trend towards an increase of relative merit.

Table 2. Rankings, ages means, heights means, weights means and relative merits of male Olympic judokas (100 kg and over) who competed at the 2012 London Olympic Games.

\begin{tabular}{|c|c|c|c|c|}
\hline Rankings & $\begin{array}{l}\text { Ages means } \\
\text { (years) }\end{array}$ & $\begin{array}{l}\text { Heights means } \\
\qquad(\mathrm{cm})\end{array}$ & $\begin{array}{l}\text { Weights means } \\
(\mathrm{kg})\end{array}$ & $\begin{array}{c}\text { Relative merits } \\
\text { (arbitrarily chosen units) }\end{array}$ \\
\hline the judoka who won in the final & 23 & 204 & 131.00 & 7 \\
\hline the judoka who has been won in the final & 33 & 195 & 115.00 & 6 \\
\hline the judokas who have been won in the semifinals & 29 & 198 & 150.00 & 5 \\
\hline $\begin{array}{l}\text { the judokas who have been won } \\
\text { in the contest for bronze medal }\end{array}$ & 29 & 186 & 128.50 & 4 \\
\hline the judokas who have been won in the quarterfinals & 27 & 195 & 118.00 & 3 \\
\hline $\begin{array}{l}\text { the judokas who have been won } \\
\text { in the elimination round of } 16\end{array}$ & 26 & 193 & 139.63 & 2 \\
\hline $\begin{array}{l}\text { the judokas who have been won } \\
\text { in the elimination round of } 32\end{array}$ & 26 & 189 & 118.69 & 1 \\
\hline
\end{tabular}


Cedric was defeated as soon as the elimination round of 32. The height of Mandembo Cedric $(180 \mathrm{~cm})$ was then lower than the mean of the heights of the judokas of any of all the classes of merit. Mikhaylin Alexander, who won Mandembo Cedric and was won himself only during the final, was $195 \mathrm{~cm}$ tall, his height being taller than the mean of the heights of all the judokas of their judo division pulled together $(194 \mathrm{~cm})$.

\subsection{Influence of the Means of the Weights of the Judokas}

Regarding the influence of the means of the weights of the judokas (Table 2 and Figure 5), it appears that, with increasing mean weight, there is a trend towards an increase of relative merit. The weight of the Congolese judoka Mandembo Cedric (120 kg) as well as that of Mikhaylin Alexander (115 kg), who won Mandembo Cedric, were closer to the mean of the weights of the judokas of lesser merit $(118.69 \mathrm{~kg})$ than closer to the mean of the weights of all the judokas of their judo division pulled together $(128.69 \mathrm{~kg})$.

\subsection{Influence of the Ages Means of the $1500 \mathrm{~m}$ Runners}

Regarding the influence of the means of the ages of the 1500 m runners (Table 3 and Figure 6), it appears that Ilunga Sankuru Chancel was only 16 years old and the youngest of the women who ran the $1500 \mathrm{~m}$ while 26 years was the mean of the ages of each of the three classes of merit in which have been split up all the women who ran the $1500 \mathrm{~m}$.

\subsection{Influence of the Heights Means of the 1500 m Runners}

Regarding the influence of the heights means of the $1500 \mathrm{~m}$ runners (Table 3 and Figure 7), it appears that, with increasing mean height, there is a trend towards an increase of relative merit. Ilunga Sankuru Chancel was only $165 \mathrm{~cm}$ tall while $165.60 \mathrm{~cm}$ was the heights mean of the runners of lesser merit.

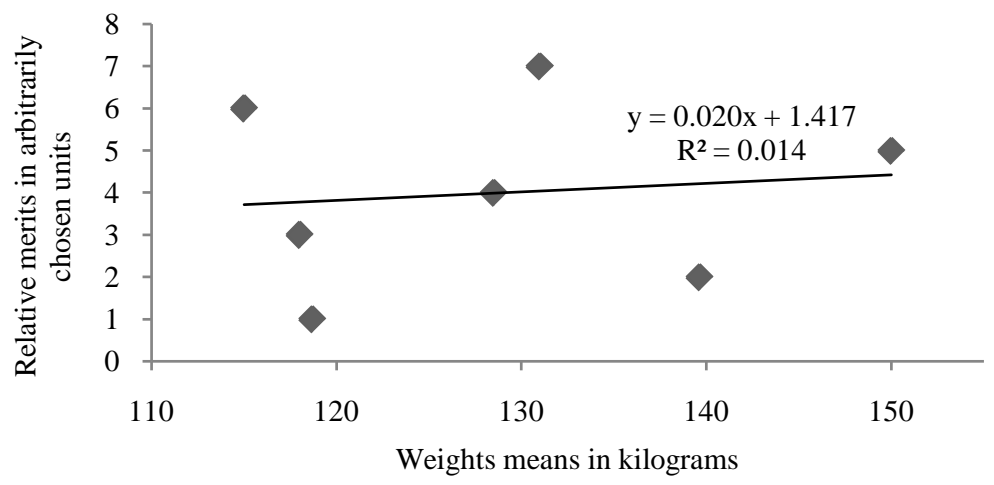

Figure 5. Relative merits at different weights means of the judokas. With increasing mean weight, there is a trend towards an increase of relative merit.

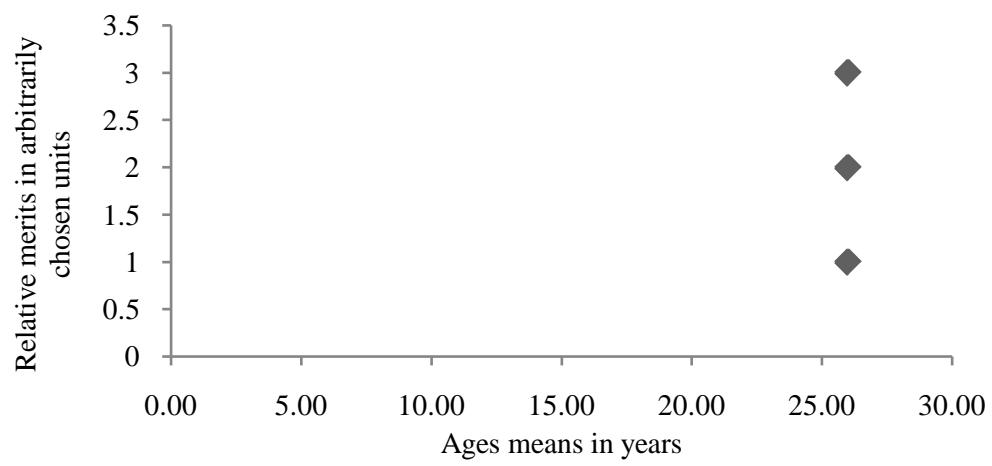

Figure 6. Relative merits at different ages means of the 1500 m runners. 26 years was the mean of the ages of each of the three merit classes in which have been split up all the women who ran the $1500 \mathrm{~m}$. 


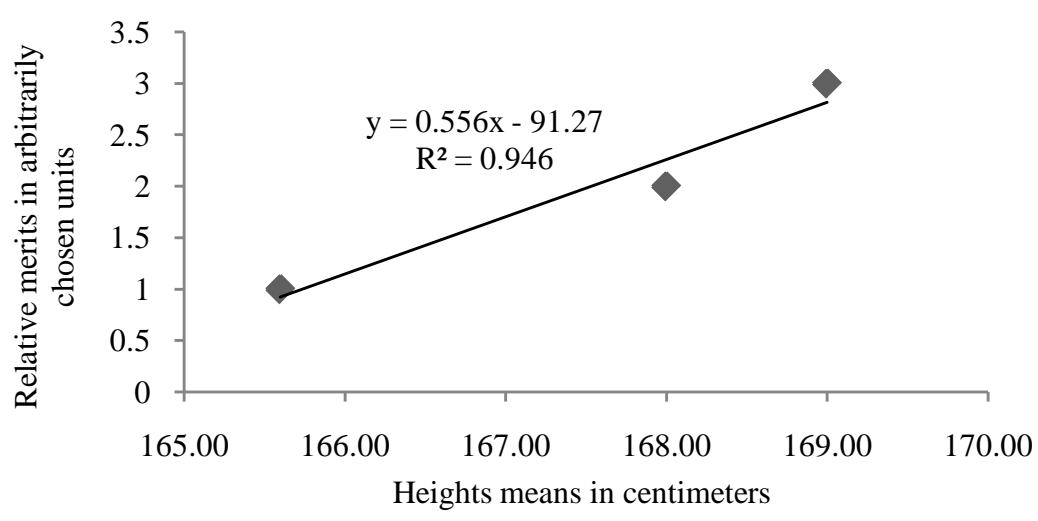

Figure 7. Relative merits at different heights means of the $1500 \mathrm{~m}$ runners. With increasing mean height, there is a trend towards an increase of relative merit.

Table 3. Rankings, ages means, heights means, weights means and relative merits of the 44 women who finished the $1500 \mathrm{~m}$ running at the 2012 London Olympic Games.

\begin{tabular}{|c|c|c|c|c|}
\hline Rankings & $\begin{array}{l}\text { Ages means } \\
\text { (years) }\end{array}$ & $\begin{array}{l}\text { Heights means } \\
\text { (cm) }\end{array}$ & $\begin{array}{l}\text { Weights means } \\
(\mathrm{kg})\end{array}$ & $\begin{array}{c}\text { Relative merits } \\
\text { (arbitrarily chosen units) }\end{array}$ \\
\hline the runners who competed in the final & 26.00 & 169.00 & 52.55 & 3 \\
\hline $\begin{array}{l}\text { the runners who have been } \\
\text { eliminated in the semifinal }\end{array}$ & 26.00 & 168.00 & 51.64 & 2 \\
\hline $\begin{array}{l}\text { the runners who have been } \\
\text { eliminated in the first round }\end{array}$ & 26.00 & 165.60 & 51.40 & 1 \\
\hline
\end{tabular}

\subsection{Influence of the Means of the Weights of the $1500 \mathrm{~m}$ Runners}

Regarding the influence of the means of the weights of the $1500 \mathrm{~m}$ runners (Table 3 and Figure 8), it appears that, with increasing mean weight, there is a trend towards an increase of relative merit. Ilunga Sankuru Chancel was only $49 \mathrm{~kg}$ heavy, a weight lighter than the mean of the weights of the $1500 \mathrm{~m}$ runners of any of all the classes of merit here concerned.

\subsection{Influence of the Means of the Ages of the Marathon Runners}

Regarding the influence of the means of the ages of the marathon runners (Table 4 and Figure 9), it appears that, with increasing mean age, there is a trend towards an increase of relative merit. However, Ilunga Zatara Mande, who did not finish the race, was only 29 years old, an age younger than the mean of the ages of the marathon runners of any of all the classes of merit.

\subsection{Influence of the Means of the Heights of the Marathon Runners}

Regarding the influence of the means of the heights of the marathon runners (Table 4 and Figure 10), it appears that, with increasing mean height, there is a trend towards an increase of relative merit. However, Ilunga Zatara Mande, who did not finish the race, was only $171 \mathrm{~cm}$ tall, a height shorter than the mean height of the class of lesser merit runners who finished the race $(171.7 \mathrm{~cm})$ as well as the mean height of all the men who ran the marathon $(173.6 \mathrm{~cm})$.

\subsection{Influence of the Means of the Weights of the Marathon Runners}

Regarding the influence of the means of the weights of the marathon runners (Table 4 and Figure 11), it appears that, with increasing mean weight, there is a trend towards an increase of relative merit. However, Ilunga Zatara Mande, who did not finish the race, was $65 \mathrm{~kg}$ heavy, a weight heavier than the mean of the weights of the marathon runners of any of all the merit classes here concerned. 


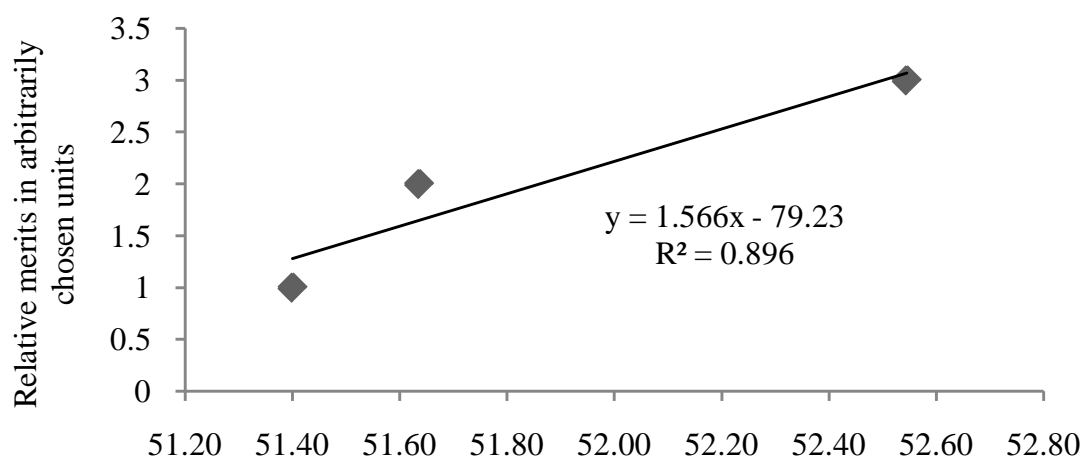

Weights means in kilograms

Figure 8. Relative merits at different weights means of the $1500 \mathrm{~m}$ runners. With increasing mean weight, there is a trend towards an increase of relative merit.

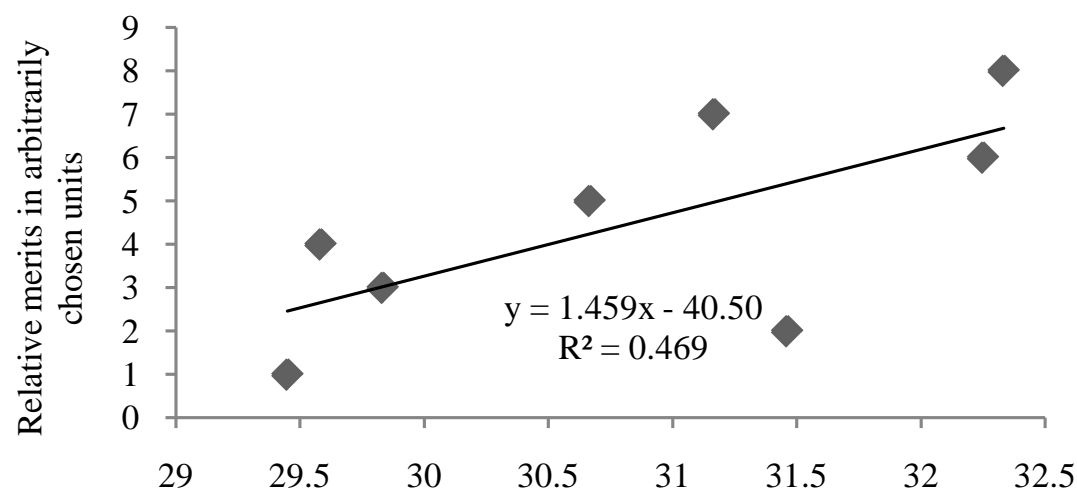

Ages means in years

Figure 9. Relative merits at different ages means of the marathon runners. With increasing mean age, there is a trend towards an increase of relative merit.

Table 4. Rankings, ages means, heights means, weights means and relative merits of the 105 male who ran the marathon at the 2012 London Olympic Games.

\begin{tabular}{|c|c|c|c|c|}
\hline Rankings & $\begin{array}{l}\text { Ages means } \\
\text { (years) }\end{array}$ & $\begin{array}{l}\text { Heights means } \\
(\mathrm{cm})\end{array}$ & $\begin{array}{l}\text { Weights means } \\
(\mathrm{kg})\end{array}$ & $\begin{array}{l}\text { Relative merits } \\
\text { (arbitrarily chosen units) }\end{array}$ \\
\hline $\begin{array}{l}\text { the } 12 \text { runners classed } 1^{\text {st }} \text { to } 12^{\text {th }} \\
\text { at the end of the race }\end{array}$ & 32.3 & 173.9 & 59.8 & 8 \\
\hline $\begin{array}{l}\text { the } 12 \text { runners classed } 13^{\text {th }} \text { to } 24^{\text {th }} \\
\text { at the end of the race }\end{array}$ & 31.2 & 174.4 & 60.2 & 7 \\
\hline $\begin{array}{l}\text { the } 12 \text { runners classed } 25^{\text {th }} \text { to } 36^{\text {th }} \\
\text { at the end of the race }\end{array}$ & 32.3 & 175.6 & 62 & 6 \\
\hline $\begin{array}{l}\text { the } 12 \text { runners classed } 37^{\text {th }} \text { to } 48^{\text {th }} \\
\text { at the end of the race }\end{array}$ & 30.7 & 175.9 & 60.9 & 5 \\
\hline $\begin{array}{l}\text { the } 12 \text { runners classed } 49^{\text {th }} \text { to } 60^{\text {th }} \\
\text { at the end of the race }\end{array}$ & 29.6 & 169.9 & 59.3 & 4 \\
\hline $\begin{array}{l}\text { the } 12 \text { runners classed } 61^{\text {st }} \text { to } 72^{\text {nd }} \\
\text { at the end of the race }\end{array}$ & 29.8 & 173.2 & 57.8 & 3 \\
\hline $\begin{array}{l}\text { the } 13 \text { runners classed } 73^{\text {rd }} \text { to } 85^{\text {th }} \\
\text { at the end of the race }\end{array}$ & 31.5 & 171.7 & 60.4 & 2 \\
\hline the 25 runners who did not finish the race & 29.5 & 174.6 & 61.1 & 1 \\
\hline
\end{tabular}




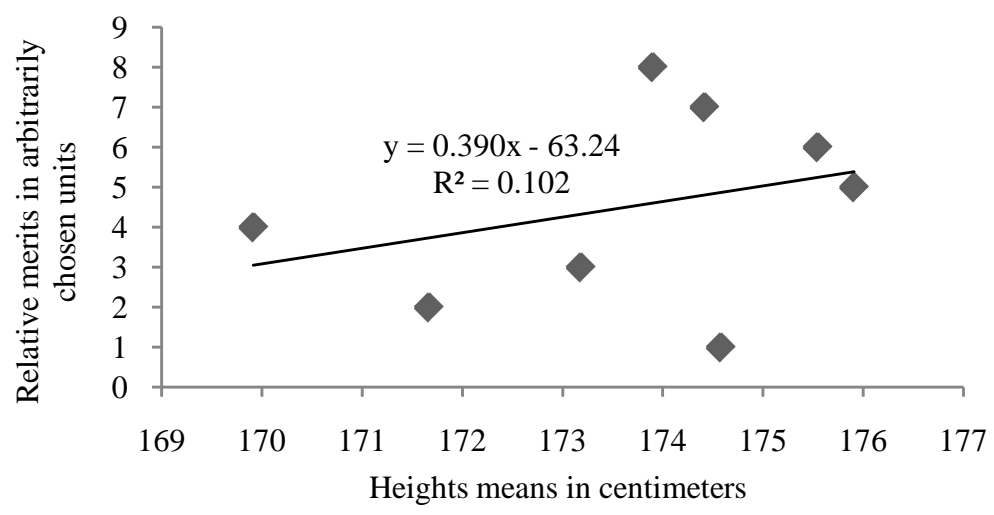

Figure 10. Relative merits at different heights means of the marathon runners. With increasing mean height, there is a trend towards an increase of relative merit.

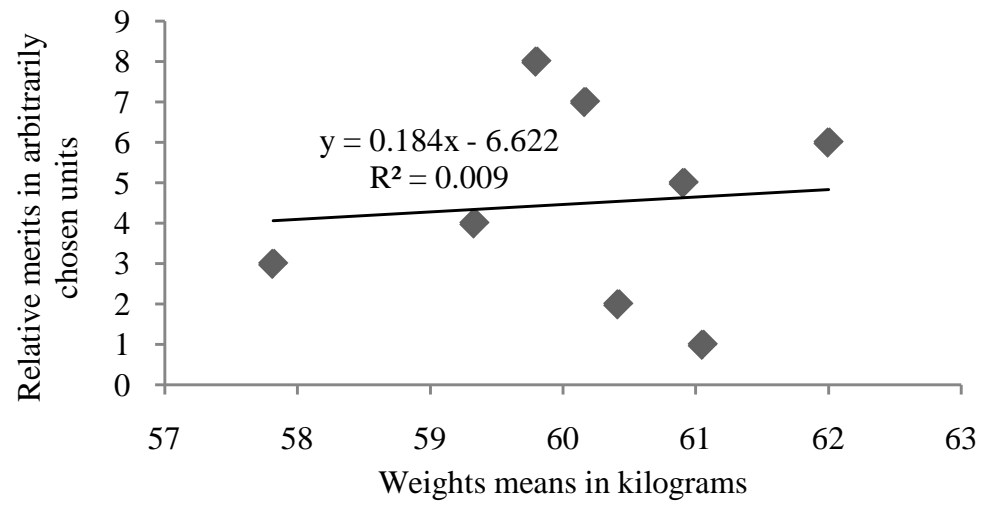

Figure 11. Relative merits at different weights means of the marathon runners. With increasing mean weight, there is a trend towards an increase of relative merit.

\section{Discussion}

\subsection{Influence of the Means of the Ages of the Boxers}

With increasing mean age, there is a trend towards an increase of relative merit. The Congolese boxer Mwamba Meji was 30 years old when he was defeated as soon as the round before the quarterfinals by Medzhidov Magomedrasul who was then 26 years old but was himself defeated only during the semifinal. The age of each of both boxers was then greater than the mean of the ages of all the boxers of their boxing division pulled together (25.8 years). Hence, the age of Mwamba Meji did not contribute to the defeat of the boxer at the 2012 London Olympic Games.

\subsection{Influence of the Means of the Heights of the Boxers}

With increasing mean height, there is a trend towards an increase of relative merit. The Congolese boxer Mwamba Meji was $195 \mathrm{~cm}$ tall when he was defeated as soon as the round before the quarterfinals by Medzhidov Magomedrasul who was then $190 \mathrm{~cm}$ tall but was himself defeated only during the semifinal. Of both boxers, it was the Congolese boxer who held a height closer to the mean of the heights of all the boxers of their boxing division pulled together $(195.3 \mathrm{~cm})$. Hence, the height of Mwamba Meji did not contribute to the defeat of the boxer at the 2012 London Olympic Games.

\subsection{Other Influences That Could Have Contributed to the Defeat of the Congolese Boxer Mwamba Meji}

The importance of age and height of a boxer may be modulated by factors others than anthropometric (physio- 
logical, economic, ethnic, etc.).

A clip on the boxing battle that opposed Mwamba Meji to Medzhidov Magomedrasul has been viewed (Chaîne de Congomikilinews, 2012). The examination of its content allows us to report factors other than anthropometric that could have contributed to the defeat of Mwamba, although we are unable to provide measured or estimated data on those influences.

Inadequate wearing of boxing helmet and wearing of boots inappropriate to boxing practice

From the beginning of the battle, contrary to the boxing helmet of Medzhidov, that of Mwamba was not suitably fastened. Being unsuitably fastened, Mwamba's boxing helmet did not allowed him, we think, to adopt a convenient guard: Mwamba's chin could not benefit from the protection of his left shoulder and his right glove against Medzhidov's punches. As a matter of fact, a punch of Medzhidov to the unprotected chin threw in the air Mwamba's boxing helmet. The referee was obliged to suspend the battle so as to permit Mwamba put back his helmet. Unfortunately for the latter, the suspension of the battle allowed the referee to realize that Mwamba was already unable to control his fear and showed insufficient combativeness during the minutes preceding the suspension of the battle, was bleeding from his face. All that obliged the referee, we think, to stop the battle, what made Medzhidov the winner.

Assuming that in the following minutes, Mwamba would have manifested more control of his fear, that his combativeness would have increased, and that the helmet had been suitably fastened, the suspension of the battle and its consequence on the decision of the battle would not have taken place, and they were going to take care of the bleeding by Mwamba's team.

Contrary to his opponent, Mwamba wore boots inappropriate to boxing practice. Speaking of the lower limbs, Mwamba is less a motionless than a moving boxer. The thick-soled and high-heeled sneakers he wore have made difficult and have slowed his revolution around Medzhidov. That may possibly have impeded Mwamba to benefit fully from the boxing tactics signaled below (see Errors of tactics).

The imperfection of Mwamba's boxing guard

Being unsuitably fastened, Mwamba's boxing helmet made his chin appear too far from his chest. The punch of Medzhidov to the unprotected chin threw in the air Mwamba's boxing helmet, with the resulting consequences aforementioned (see Inadequate wearing of boxing helmet and wearing of boots inappropriate to boxing practice).

\section{Errors of tactics}

From a qualitative standpoint, both boxers adopted attitudes appropriate to their heights. Medzhidov, the shorter boxer, attacked continually, moving forward towards his opponent, while Mwamba, the taller boxer, revolved around Medzhidov, what reminds us of Muhammad Ali. But, unfortunately, Mwamba revolved towards his own left only to protect himself against the punches of his opponent.

From a quantitative standpoint, the revolution of Mwamba was adapted to his opponent attacks (the opponent imposed the pace of the battle and Mwamba was thus more prone to the defeat than Medzhidov). Mwamba would better have boxed more rapidly than his opponent to impose his own pace to the battle and thus increase his chances of winning. An advantage of revolving more rapidly is that whenever he could have stopped the revolution or whenever he could suddenly have changed the direction of his revolution (towards his own right), Mwamba would have surprised his opponent with more defenseless legal targets of the anterior surface as well as of one of both lateral surfaces.

The face of Mwamba showing fear of Medzhidov's attacks

The fact of holding a height taller than the one of one's opponent is the sign of being better strategist than the opponent. As a matter of fact, individuals higher than others have been said well tooled for survival, a correlation being found between the height and cleverness (Vandervael, 1980). The fact of holding a height shorter than the one of one's opponent is the sign of having more easiness than the opponent, speaking of performing any kind of physical action (Monod, Flandrois, \& Vandewalle, 2007).

As aforesaid, a factor other than anthropometric may modulate the influence of an anthropometric factor. The fear, and specially the fact of showing a lack of the fear control, is one of the modulating factors. Mwamba fear of Medzhidov's attacks could possibly have impeded Mwamba to benefit from the advantage of holding a height taller than that of his opponent. The face of Mwamba showing fear of Medzhidov's attacks could possibly have helped Medzhidov to decrease his own fear of the opponent's attacks and thus fully benefit from his own possession of the shorter height. 


\subsection{Influence of Means of the Ages of the Judokas}

The Congolese judoka Mandembo Cedric was 28 years old, an age as great as the mean of the ages of all the judokas of their judo division pulled together, when he was defeated as soon as the elimination round of 32 by Mikhaylin Alexander who was 33 years old but was himself defeated only during the final. However, with increasing mean age, there is a trend towards an increase of relative merit. Hence, at the 2012 London Olympic Games, the age did not contribute by itself to the defeat but it constituted a relative disadvantage for Mandembo Cedric, when compared with the age of his opponent.

\subsection{Influence of the Means of the Heights of the Judokas}

With increasing mean height, there is a trend towards an increase of relative merit. The Congolese judoka Mandembo Cedric was defeated as soon as the elimination round of 32. The height of Mandembo Cedric $(180 \mathrm{~cm})$ was lower than the mean of the heights of the judokas of any of all the classes of merit here concerned. Mikhaylin Alexander, who won Mandembo Cedric and was won himself only during the final, was $195 \mathrm{~cm}$ tall, his height being taller than the mean of the heights of all the judokas of their judo division pulled together $(194 \mathrm{~cm})$. Hence, the height of Mandembo Cedric contributed to his defeat at the 2012 London Olympic Games.

\subsection{Influence of the Means of the Weights of the Judokas}

With increasing mean weight, there is a trend towards an increase of relative merit. The weight of the Congolese judoka Mandembo Cedric (120 kg) as well as that of Mikhaylin Alexander (115 kg), who won Mandembo Cedric, were closer to the mean of the weights of the judokas of lesser merit $(118.69 \mathrm{~kg})$ than closer to the mean of the weights of all the judokas of their judo division pulled together $(128.69 \mathrm{~kg})$. The weight constituted thus an advantage for the Congolese judoka and, hence, did not contribute to the defeat of the judoka at the 2012 London Olympic Games.

\subsection{Influence of the Means of the Ages of the $1500 \mathrm{~m}$ Runners}

Ilunga Sankuru Chancel was only 16 years old and the youngest of the women who ran the $1500 \mathrm{~m}$ while 26 years was the mean of the ages of each of the three merit classes in which have been split up all the women who ran the $1500 \mathrm{~m}$. The young age of Ilunga Sankuru Chancel contributed thus to the defeat of the Congolese runner at the 2012 London Olympic Games.

\subsection{Influence of the Means of the Heights of the $1500 \mathrm{~m}$ Runners}

With increasing mean height, there is a trend towards an increase of relative merit. Ilunga Sankuru Chancel was only $165 \mathrm{~cm}$ tall while $165.60 \mathrm{~cm}$ was the mean of the heights of the runners of lesser merit. The short height contributed thus to the defeat of the Congolese runner at the 2012 London Olympic Games.

\subsection{Influence of the Means of the Weights of the $1500 \mathrm{~m}$ Runners}

With increasing mean weight, there is a trend towards an increase of relative merit. Ilunga Sankuru Chancel was only $49 \mathrm{~kg}$ heavy, a weight lighter than the mean of the weights of the runners of any of all the classes of merit. The light weight contributed thus to the defeat of the Congolese runner at the 2012 London Olympic Games.

\subsection{Influence of the Means of the Ages of the Marathon Runners}

With increasing mean age, there is a trend towards an increase of relative merit. However, Ilunga Zatara Mande, who did not finish the race, was only 29 years old, an age younger than the mean age of any of the classes of merit here concerned. The young age of Ilunga Zatara Mande contributed thus to the defeat of the Congolese runner at the 2012 London Olympic Games.

\subsection{Influence of the Means of the Heights of the Marathon Runners}

With increasing mean height, there is a trend towards an increase of relative merit. However, Ilunga Zatara Mande, who did not finish the race, was only $171 \mathrm{~cm}$ tall, a height shorter than the mean height of the class of 
lesser merit runners who finished the race $(171.7 \mathrm{~cm})$ as well as the mean height of all the men who ran the marathon $(173.6 \mathrm{~cm})$. The short height of Ilunga Zatara Mande contributed thus to the defeat of the Congolese runner at the 2012 London Olympic Games.

\subsection{Influence of the Means of the Weights of the Marathon Runners}

With increasing mean weight, there is a trend towards an increase of relative merit. However, Ilunga Zatara Mande, who did not finish the race, was $65 \mathrm{~kg}$ heavy, a weight heavier than the mean of the weights of the marathon runners of any of all the classes of merit who finished the race. The heavy weight of Ilunga Zatara Mande did not thus contribute to the defeat of the Congolese runner at the 2012 London Olympic Games.

\section{Conclusion}

\subsection{Boxing}

Neither the age nor the height of the Congolese boxer Mwamba Meji had contributed to the defeat of the Con golese boxer at the 2012 London Olympic Games. Nonetheless, there is a possible contribution of non anthropometric unfavorable factors to the early defeat of the boxer (inadequate wearing of boxing helmet, wearing of boots inappropriate to boxing practice, errors of tactics, presence on the face of fear of the opponent's attacks).

\subsection{Judo}

The short height of the Congolese judoka Mandembo Cedric contributed to the soon defeat of the judoka at the 2012 London Olympic Games. The age did not contribute by itself to the defeat but constituted a relative disadvantage for Mandembo Cedric, when compared with that of his opponent.

\subsection{0 m Running}

The too young age, the too short height and the too light weight of the Congolese $1500 \mathrm{~m}$ female runner Ilunga Sankuru Chancel had contributed to the early defeat of the runner at the 2012 London Olympic Games.

\subsection{Marathon Running}

The too young age as well as the too short height of the Congolese marathon male runner Ilunga Zatara Mande contributed to the early stop of the race by the runner.

\subsection{What Must Be Done to Increase the Chances of Competitors at the Olympic Games Next to 2012 London Olympic Games}

The means computed from the values obtained on the persons who competed at the 2012 Olympic Games would better be taken into account: selection would better be principally made from competitors whose anthropometric factors values do not stand too apart from the means computed from the values obtained on the persons who competed at the 2012 Games.

Hence, male boxers (more than $91 \mathrm{~kg}$ ) would better hold 25.8 years old and $195.3 \mathrm{~cm}$ height. Male judokas (100 kg and over) would better hold 28 years old, $194 \mathrm{~cm}$ height and $128.69 \mathrm{~kg}$ weight. Women $1500 \mathrm{~m}$ runners would better hold 26 years old, $167.5 \mathrm{~cm}$ height and $51.86 \mathrm{~kg}$ weight. Male marathon runners would better hold 30.8 years old, $173.6 \mathrm{~cm}$ height and $60.19 \mathrm{~kg}$ weight.

Especially in the cases that at least one of the aforesaid conditions is not fulfilled, coaches would better optimize factors of success other than age, height and weight (technical factors, tactical factors, psychological factors, etc.).

Persons who will accompany competitors to the Olympic Games would better be prepared to bring back home films illustrating sportsmen and sportswomen behavior during the competition.

\section{Perspective}

In some poor regions of the World, there exists a lack of most recently internationally approved testing tools for identification of the candidates more advantaged than others to given sports practice, as well as for the selection 
of competitors among too numerous candidates (specific ergometers, biochemical and haematological tests, high-speed videography, accelerometers, etc.).

A former study signals that professional boxing performance may benefit from pertaining of the boxer to a given zodiacal sign and that we are already in search for other deep tools usable for the aforesaid identification and selection (Mukala Nsengu Tshibangu, 2014). The present study shows that computing the age, measuring the height and/or measuring the weight of a person results helpful.

It could be interesting to examine the extent to which the zodiacal signs influence the performances of the concerned competitors at the Olympic Games (non professional sportsmen and sportswomen).

\section{Acknowledgements}

Not applicable.

\section{References}

Ackland, T. R., Bloomfield, J., \& Elliot, B. C. (2009). The Assessment and Modification Model. In T. R. Ackland, B. C. Elliot, \& J. Bloomfield (Eds.), Applied Anatomy and Biomechanics in Sport (pp. 3-9). Champaign, IL: Human Kinetics.

Chaîne de Congomikilinews (2012). Le congolais Mwamba Meji quitte la compétition sans démérité. http://www.youtube.com/watch?v=GVP-lu97Aow

Daniel, W. W. (1987). Biostatistics: A Foundation for Analysis in the Health Sciences $\left(4^{\text {th }}\right.$ ed.). New York: John Wiley \& Sons.

Monod, H., Flandrois, R., \& Vandewalle, H. (2007). Physiologie Du Sport. Paris: Elsevier Masson.

Mukala Nsengu Tshibangu, A. (2014). Boxing Performance May Benefit from Pertaining of the Boxer to a Given Zodiacal Sign. Advances in Physical Education, 4, 29-35. http://dx.doi.org/10.4236/ape.2014.41005

Olds, T. S., \& Tomkinson, G. R. (2009). Absolute Body Size. In T. R. Ackland, B. C. Elliot, \& J. Bloomfield (Eds.), Applied Anatomy and Biomechanics in Sport (pp. 29-46). Champaign, IL: Human Kinetics.

Parker, R. E. (1979). Introductory Statistics for Biology (2nd ed.). New York: Cambridge University Press.

The London Organising Committee of the Olympic Games and Paralympic Games Limited (2012a). Men’s +100kg—Olympic Judo London 2012. http://www.london2012.com/judo/event/men-more-than-100kg/standing.html

The London Organising Committee of the Olympic Games and Paralympic Games Limited (2012b). Men’s Marathon-Olympic Athletics London 2012. http://www.london2012.com/athletics/event/men-marathon/index.html

The London Organising Committee of the Olympic Games and Paralympic Games Limited (2012c). Men’s Super Heavy (+ $91 \mathrm{~kg}$-OOlympic Boxing London 2012. http://fr.london2012.com/fr/boxing/event/men-super-heavy-more-than-91kg/standing.html

The London Organising Committee of the Olympic Games and Paralympic Games Limited (2012d). Women's 1500 m-Olympic Athletics London 2012.

http://www.london2012.com/athletics/event/women-1500m/phase=atw015900/index.html http://www.london2012.com/athletics/event/women-1500m/phase=atw015200/index.html http://www.london2012.com/athletics/event/women-1500m/phase=atw015100/index.html

Vandervael, F. (1980). Biométrie Humaine. Paris: Masson. 